\title{
Base temperature for leaf appearance and phyllochron of selected strawberry cultivars in a subtropical environment
}

\author{
Hamilton Telles Rosa ('); Lidiane Cristine Walter (2); Nereu Augusto Streck ( ${ }^{*}$ ); Jerônimo Luiz \\ Andriolo ( $\left.{ }^{3}\right)$; Michel Rocha da Silva ( $\left.{ }^{4}\right)$; Josana Andréia Langner $\left({ }^{4}\right)$ \\ (') Universidade Federal de Santa Maria (UFSM), Programa de Pós-Graduação em Agronomia, Av. Roraima, 1000, $97105-900$ Santa \\ Maria (RS) Brasil. \\ (2) UFSM, Programa de Pós-Graduação em Engenharia Agrícola, Av. Roraima, 1000, 97105-900 Santa Maria (RS), Brasil. \\ (3) UFSM, Departamento de Fitotecnia, 97105-900 Santa Maria (RS), Brasil. \\ (4) UFSM, Graduação em Agronomia, Av. Roraima, 1000, 97105-900 Santa Maria (RS), Brasil. \\ (*) Corresponding author: nstreck1@smail.ufsm.br
}

Received: October 7, 2010; Accepted: March 18, 2011.

\begin{abstract}
Leaf development is characterized by the appearance of new leaves and is related to crop leaf area index, which affects the interception of solar radiation used for photosynthesis and biomass production and ultimately defines crop yield. The objectives of this paper were to estimate the base temperature for leaf appearance and to determine the phyllochron of two strawberry cultivars considering several planting dates. A two-year field experiment was conducted during 2008 and 2009 in Santa Maria (RS). The cultivars Arazá (early) and Yvapitá (late) were used at three planting dates in both years. Base temperature (Tb) was estimated using the Mean Square Error (MSE) approach of the regression between accumulated leaf number (LN) and accumulated thermal time (ATT). The phyllochron was calculated as the inverse of the slope of the regression of LN against ATT. Estimated Tb for leaf appearance in both cultivars was $0^{\circ} \mathrm{C}$. Variations in phyllochron were observed among the two cultivars, among planting dates and also during the plant developmental period of each cultivar. Before flowering, the phyllochron was similar in both cultivars and after flowering it was higher in cultivar Arazá. Phyllochron was greater for later planting dates and increased at short photoperiods in Fall and Winter. Results showed that both cultivars have a typical longday plant response because phyllochron decreased as photoperiod increased up to approximately 11.8 hours, and phyllochron was the lowest at longer photoperiod.
\end{abstract}

Key words: Fragaria x ananassa, leaf development, plant development, temperature, thermal time.

\section{Temperatura-base de emissão de folhas e filocrono de algumas cultivares de morangueiro em ambiente subtropical}

\section{Resumo}

O desenvolvimento foliar é caracterizado pelo aparecimento de novas folhas e relacionado com o índice de área foliar da cultura, que afeta a interceptação de radiação solar usada na fotossíntese e produção de biomassa e que, em ultima análise, define a produtividade da cultura. Os objetivos deste trabalho foram estimar a temperatura-base de aparecimento de folhas e determinar o filocrono em duas cultivares de morangueiro em diferentes datas de plantio. Um experimento de campo foi desenvolvido em 2008 e 2009 em Santa Maria (RS). Foram utilizadas as cultivares Arazá (precoce) e Yvapitá (tardia) em três datas de plantio em cada ano. A temperatura-base (Tb) foi estimada pela metodologia de menor Quadrado Médio do Erro (QME) da regressão linear entre o número de folhas acumuladas (NF) e a Soma Térmica acumulada (STa). O filocrono foi calculado pelo inverso do coeficiente angular da regressão linear entre NF e STa. A Tb estimada para o aparecimento de folhas das cultivares foi de $0^{\circ} \mathrm{C}$. O filocrono variou durante o ciclo de desenvolvimento, sendo maior após a floração. Até a floração, o filocrono foi similar nas duas cultivares e após o início do florescimento o filocrono foi maior na cultivar Arazá. O filocrono é maior em datas de plantio mais tardias, durante o outono e o inverno, quando o fotoperíodo é menor, uma resposta típica de planta de dia longo; o filocrono diminuiu quando o fotoperíodo aumentou em até aproximadamente 11,8 horas, sendo menor em fotoperíodos mais longos.

Palavras-chave: Fragaria x ananassa, desenvolvimento folhas, desenvolvimento vegetal, temperatura, soma térmica. 


\section{INTRODUCTION}

In strawberry (Fragaria $x$ ananassa), the development and growth of leaves, inflorescences and stolons are controlled by complex interactions among environmental variables mainly temperature, photoperiod and daily thermal amplitude (Heide and Sonsteby, 2007; Oliveira and Scivittaro, 2009; Bradford, 2010). A main variable that has been used to describe leaf development of agricultural crops is the number of accumulated leaves (LN) on the main stem (STRECK et al., 2003a). The LN is a result of the integration of leaf appearance rate (LAR) over time, and $\mathrm{LN}$ is related to crop leaf area index, which affects the interception of solar radiation used for photosynthesis and biomass production that ultimately defines crop yield (Sinclair et al., 2004). One way to estimate LAR is using the concept of phyllochron, defined as the time interval between the appearance of successive leaves on a stem, with dimension of [time].[leaf] ${ }^{-1}$ (KLepper et al., 1982).

One approach to take into account the effect of temperature on plants is the thermal time, with units of ${ }^{\circ} \mathrm{C}$ day (STreck, 2002). The assumption when using the thermal time approach is that when temperature is below a lower threshold $(\mathrm{Tb})$, plant development does not take place or it does at very low rates that can be neglected, and when temperature increases above $\mathrm{Tb}$, developmental rate increases in a linear fashion up to the optimum temperature (McMaster and Wilhelm, 1997; Streck, 2002). Using the thermal time approach, the phyllochron is the number of degree-days between the appearance of two successive leaves, with unit of $\left({ }^{\circ} \mathrm{C} \text { day) (leaf) }\right)^{-1}$ (XuE et al., 2004). For strawberry, $7.2^{\circ} \mathrm{C}$ has been considered as the Tb to break dormancy (Durner et al., 1984; SERÇE and Hancock, 2005). For thermal time calculations during plant development of four Californian strawberry cultivars grown in Passo Fundo, RS, Antunes et al. (2006), used the $\mathrm{Tb}$ of $7^{\circ} \mathrm{C}$ from the literature. This base temperature was also used for calculating chilling hours for breaking dormancy in cold dormant cultivars (Gimenez et al., 2003) while STRAND (1994) argued that the base temperature for crown growth and development is $10{ }^{\circ} \mathrm{C}$. TANINO and WANG (2008) reported the range of effective chilling temperatures from -2 to $15^{\circ} \mathrm{C}$. These $\mathrm{Tb}$ values reported in the literature are not for leaf appearance, but for other developmental processes such as flower differentiation at the apex. A literature search yielded neither report on $\mathrm{Tb}$ for leaf appearance nor attempts to determine the phyllochron in strawberry, which constituted the rationale for this study.

A first look at our data by plotting LN against ATT showed a change in the slope of the relationship, indicating change in the rate of leaf appearance throughout the growing season. Such change occurred nearly flowering suggesting the hypothesis that leaf appearance on the main crown is different before and after flowering, i.e. there is a breakpoint in leaf appearance rate at flowering in strawberry. We tested this hypothesis by defining three phyllochron phases: a single phyllochron for the entire growing season ( $\mathrm{PHYL}_{\mathrm{TOT}}$ ), a phyllochron from planting to flowering $\left(\mathrm{PHYL}_{\mathrm{VEG}}\right)$, and a phyllochron after the onset of flowering $\left(\mathrm{PHYL}_{\mathrm{FLO}}\right)$.

The objectives of this study were to estimate the base temperature for leaf appearance and to determine the phyllochron of two strawberry cultivars considering several planting dates.

\section{MATERIAL AND METHODS}

A two-year field experiment with strawberry was conducted during 2008 and 2009 at Santa Maria, RS, Brazil (latitude $29^{\circ} 43^{\prime} \mathrm{S}$; longitude $53^{\circ} 43^{\prime} \mathrm{W}$ and altitude $95 \mathrm{~m}$ ), located in the Central Region of Rio Grande do Sul State. The region has a humid subtropical climate with warm summer, which corresponds to a Cfa formula according to the Köppen system. The soil at the experimental site is a transition between the Unidade de Mapeamento São Pedro (Argissolo Vermelho distrófico arênico) and the Unidade de Mapeamento Santa Maria (Alissolo Hipocrômico argilúvico típico) according to the Brazilian Soil System (Embrapa, 1999).

Two strawberry cultivars were used in this study: INIA-Arazá and INIA-Yvapitá (INIA, Uruguay). These cultivars were developed by Instituto Nacional de Investigación Agropecuaria - INIA - Uruguay, adapted for growing at low altitudes such as in Santa Maria and surrounding areas, and have been recently introduced in the Central Region of Rio Grande do Sul State. Furthermore, these cultivars are very different in development and growth habit. Arazá has low vigor, early harvesting and is adapted to protected cultivation while Yvapitá has high vigor, late harvesting and is adapted to open field cropping. Six planting dates (three each year) were performed (month/day/year): 4/3/2008, 5/7/2008, $6 / 2 / 2008,2 / 2 / 2009,4 / 2 / 2009$ and 6/2/2009. These planting dates were chosen in order to have plants growing at different environmental conditions as they represent planting dates before, during and after the recommended planting time for this location, which is from $04 / 15$ to $05 / 30$ (EMBrapa, 2005). Seedlings were produced in a soilless growing system inside a plastic greenhouse (GimenEz et al., 2008) and planted at the 4-6 leaves stage.

Soil was plowed and disked, and $1.2 \mathrm{~m}$ width raised beds were prepared with a microtractor. Beds were fertilized with $20 \mathrm{~kg} \mathrm{ha}^{-1}$ of $\mathrm{N}, 60 \mathrm{~kg} \mathrm{ha}^{-1}$ of $\mathrm{P}_{2} \mathrm{O}_{5}$ and $50 \mathrm{~kg} \mathrm{ha}^{-1}$ of $\mathrm{K}_{2} \mathrm{O}$. Beds were mulched with $50 \mu \mathrm{m}$ black opaque polyethylene film and drip irrigation lines laid on the beds surface under the mulch provided water and fertilizers (EMBrapa, 2005). Seedlings were planted on the 
mulched beds in a $0.25 \mathrm{mx} 0.25 \mathrm{~m}$ spacing, resulting in a plant density of 10 plants $\mathrm{m}^{-2}$. Fertigation was applied to supply water and nutrients accordingly and following the recommended management for high yield (EMBRAPA, 2005).

The experimental design was a complete randomized block design with four replications. Each replication was a $1.2 \mathrm{~m} \times 3.0 \mathrm{~m}$ bed with 36 plants. After planting, six plants per replication were tagged with colored wires, which were used to count the number of leaves on the main crown (LN) on a weekly basis. A leaf was counted when the blades of its foliolates were not touching. The date of anthesis (first flower was open) in each tagged plant was recorded and the onset of flowering was considered when $50 \%$ of these plants were at anthesis.

Daily minimum and maximum air temperatures throughout the experimental period were measured in a conventional weather station of the Brazilian National Weather Service $\left(8^{\circ} \mathrm{DISME} / \mathrm{INMET}\right)$ located about $80 \mathrm{~m}$ from the experimental site. Daily mean air temperature (Tmean) was calculated by the arithmetic average of daily minimum and maximum temperature. Daily thermal time (DTT, ${ }^{\circ} \mathrm{C}$ day) was calculated as (STRECK, 2002; Rosa et al., 2009):

$\mathrm{DTT}=($ Tmean $-\mathrm{Tb}) .1$ day,

if Tmean $<\mathrm{Tb}$ then $\mathrm{Tmean}=\mathrm{Tb}$

were $\mathrm{Tb}$ is the base temperature and Tmean is the daily mean temperature. The accumulated thermal time from planting (ATT) was calculated by adding up the DTT values, i.e. $\mathrm{ATT}=\sum \mathrm{DTT}$.

The $\mathrm{Tb}$ in equation (1) was estimated using the approach by SincLaIr et al. (2004). This approach consists of estimating linear regressions between LN and ATT by setting different $\mathrm{Tb}$ values. We used $\mathrm{Tb}$ values varying from 0 to $17^{\circ} \mathrm{C}$, with step increases of $0.5^{\circ} \mathrm{C}$. The $\mathrm{Tb}$ that yields the lowest mean square error (MSE) of these linear regressions is assumed to be the Tb (SINCLAir et al., 2004).

Once the $\mathrm{Tb}$ was estimated for each cultivar, a linear regression between main crown LN and ATT was performed for each replication (average of the six tagged plants) (STRECK et al., 2007). The phyllochron was calculated by the inverse of the slope of these linear regressions (STRECK et al., 2005a; XUE et al., 2004).

Phyllochron data were analyzed considering a factorial with three main effects: Factor $\mathrm{A}=$ cultivars (two cultivars), Factor $\mathrm{B}=$ planting dates (six plantings) and Factor $\mathrm{C}=$ phyllochron phase (three phyllochrons). Statistical analysis was performed using ANOVA and the significance of differences in phyllochron means was tested with the Tukey's test at $5 \%$ probability. Statistical analyses were performed in SAS.

\section{RESULTS AND DISCUSSION}

Regression equations between $\mathrm{LN}$ and accumulated thermal time (ATT) for $\mathrm{Tb}$ values varying from 0 to $17^{\circ} \mathrm{C}$, with step increases of $0.5^{\circ} \mathrm{C}$, had coefficient of determination $\left(r^{2}\right)$ values higher than 0.95 . The mean square error (MSE) of these regressions were lower than 0.45 in the 2008 growing season and lower than 3.1 in 2009 growing season. The slope of the linear regressions were highly significant $(p<0.000001)$. The plots of MSE of the regression equations as a function of $\mathrm{Tb}$ values assumed in the calculation of thermal time (SincLair et al., 2004) for the two strawberry cultivars in the different planting dates in the two growing seasons are in Figure 1. Base temperature $(\mathrm{Tb})$ values for leaf appearance estimated for the two strawberry cultivars was $0{ }^{\circ} \mathrm{C}$ in all planting dates except for the cultivar Arazá in the 6/2/2008 planting date, which had the lowest MSE at a $\mathrm{Tb}$ of $6.5^{\circ} \mathrm{C}$. However, for this planting date $(6 / 2 / 2008)$ there was little variation in the MSE values from $0{ }^{\circ} \mathrm{C}$ to $6.5^{\circ} \mathrm{C}$ (Figure 1a), and the MSE value at $6.5^{\circ} \mathrm{C}(\mathrm{MSE}=0.046)$ was close to the MSE at $0{ }^{\circ} \mathrm{C}$ (MSE $=0.050$ ). Little variation in MSE from $9{ }^{\circ} \mathrm{C}$ to $13^{\circ} \mathrm{C}$ was also found by SinCLAir et al. (2004) when using this approach for estimating $\mathrm{Tb}$ for leaf appearance in sugarcane. In the range of little variation of MSE, SINCLAIR et al. (2004) considered that there is only a small error in calculating thermal time and thus can be assumed not affecting leaf appearance rate. From these results we assumed that $\mathrm{Tb}$ for leaf appearance in strawberry is $0{ }^{\circ} \mathrm{C}$.

Leaf differentiation and appearance overlap flower differentiation and flowering in perennials such as strawberry. Thus, it is reasonable to assume that these processes have different cardinal temperatures, as in winter cereals like wheat (STRECK et al., 2003a,b). This hypothesis is supported by our field data, as temperatures fell below $7{ }^{\circ} \mathrm{C}$ in several days during the two growing seasons but leaf appearance did not stop until $0{ }^{\circ} \mathrm{C}$. Therefore, the $\mathrm{Tb}$ of $0{ }^{\circ} \mathrm{C}$ for leaf appearance in the two strawberry cultivars used in this study is indeed realistic and biologically sound and, therefore, this value was further used in the calculations of thermal time for determining the phyllochron.

Pooling data of LN of the three planting dates for each cultivar in each year, the results showed a linear relationship between LN and ATT, with an overall coefficient of determination $\left(\mathrm{r}^{2}\right)$ between 0.92 and 0.98 (Figure 2a,b,c,d). When LN was regressed against ATT for each cultivar and planting date, the coefficient of determination was higher (data not shown). This is an indication that air temperature is the main variable driving leaf appearance in strawberry and that the estimation of the phyllochron using the regression approach is appropriate (STRECK et al., 2005a,b; XUE et al., 2004). When two regressions were fitted to the data, a significant change in the slope was observed for all planting dates in both cultivars, with a breakpoint between 1500 and $2000^{\circ} \mathrm{C}$ day, at the onset 
(a)

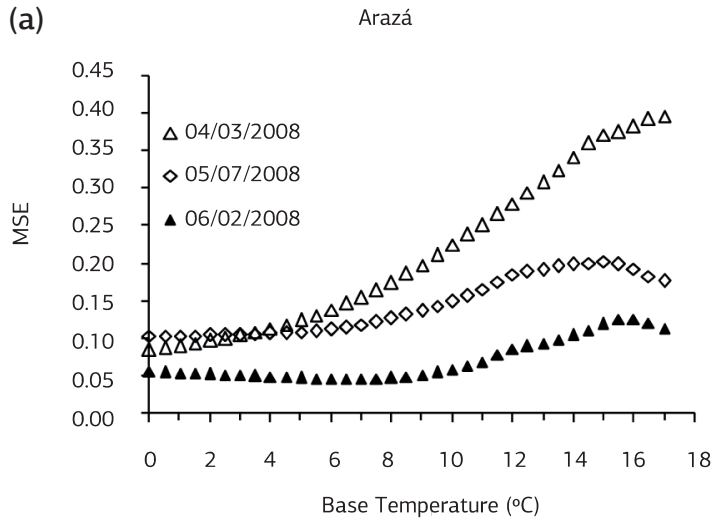

(c)

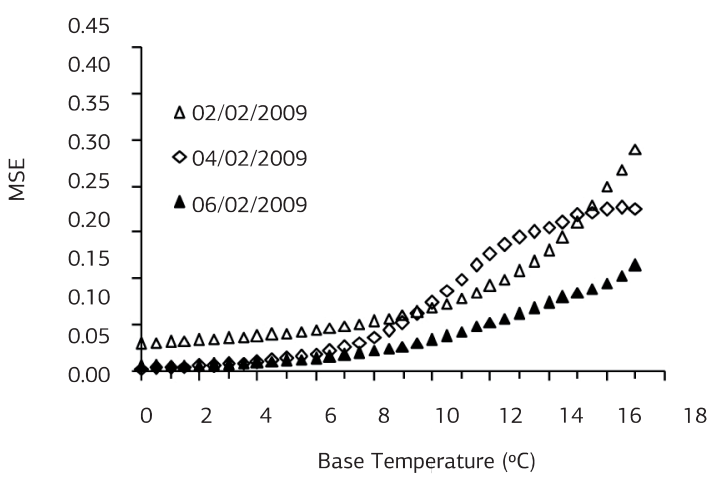

(b)

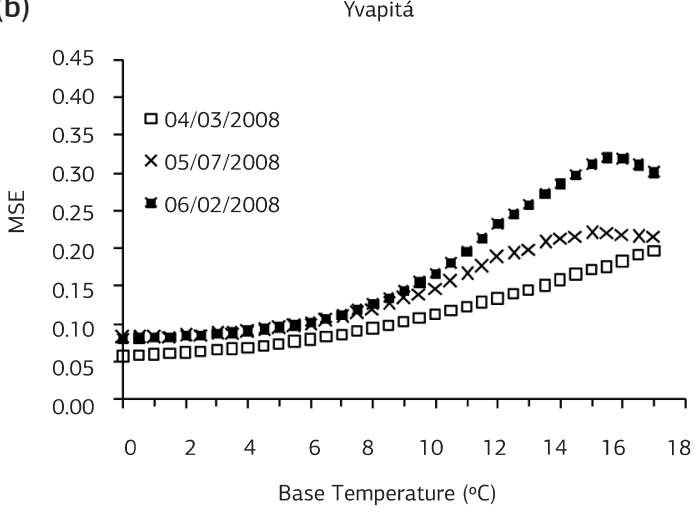

(d)

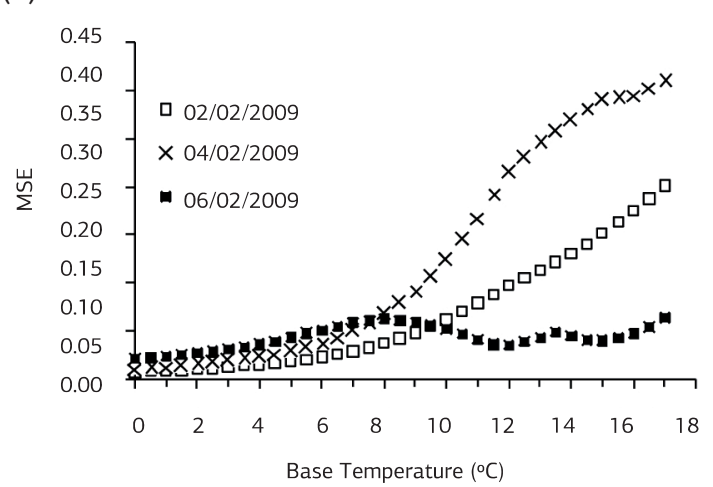

Figure 1. Mean square error (MSE) of the linear regressions between leaf number on the main crown and accumulated thermal time as a function of the base temperature assumed in the calculation of thermal time for two strawberry cultivars (Arazá and Yvapitá) in several planting dates (indicated inside each panel) in the 2008 (a,b) and 2009 (c,d) growing seasons. Santa Maria (RS).

of flowering (Figure 2e,f). Splitting the regression analysis of LN on ATT into before and after flowering, a higher coefficient of determination and a lower p-value of the slope were obtained, indicating that the breaking point at flowering is realistic (Figure 2e,f). These results suggest that leaf appearance rate changes when strawberry plants enter in the reproductive phase.

ANOVA indicated that among the main effects on phyllochron (cultivar, planting date and phyllochron phase), the highest mean square was for the phyllochron phase and the lowest was for cultivar, suggesting that the phyllochron is more affected by the ontogeny of the crop and by the environment than by the genetic constitution of these two cultivars. Interactions among the three main effects (cultivars x planting dates $\mathrm{x}$ phyllochron phase) were not significant. Among the two-factor interactions, the cultivars $\mathrm{x}$ planting dates and phyllochron phase $\mathrm{x}$ planting dates interactions were significant at $5 \%$ and the cultivars x planting dates interaction was not significant. Statistical analysis was then split accordingly (Table 1).

Among the phyllochron phases, phyllochron decreased in the sequence $\mathrm{PHYL}_{\mathrm{FLO}}>\mathrm{PHYL}_{\mathrm{TOT}}>\mathrm{PHYL}_{\mathrm{VEG}}$ for both cultivars and planting dates (Table 1). For cultivar Arazá, the three phyllochron phases were different while for cultivar Yvapitá PHYL $\mathrm{TOT}_{\text {and }} \mathrm{PHYL}_{\mathrm{VEG}}$ it did not differ. Among planting dates, phyllochron phases did not differ in the 2/6/2008 planting date and they did differ in the 4/3/2008 and 4/2/2009 planting dates while in the other three planting dates PHYL $_{\text {TOT }}$ and PHYL $_{\mathrm{VEG}}$ did not differ. These results indicate that the rate of leaf appearance in strawberry is different throughout the growing season, with greater rate (lower phyllochron) before the reproductive developmental phase. Two hypotheses can be ascribed to explain these results. Firstly, the change from vegetative to reproductive developmental stages is induced by plant hormones. In some plants, emission of vegetative organs is strongly reduced or stopped at reproductive stages. In sugarcane, differences in the rate of leaf appearance throughout the growing season were reported, with the first 15 leaves having higher leaf appearance rate than the later ones (Sinclair et al., 2004). In wheat, the relationship between LN and ATT was also bilinear, with breakpoint in the slope at double ridge, which corresponds to the onset of the reproductive development (Kirby, 1995). The second hypothesis is related to the availability of assimilates. During the reproductive phase, the growth of vegetative organs compete for photoassimilates with storage organs like fruits, and emission of new 
(a)

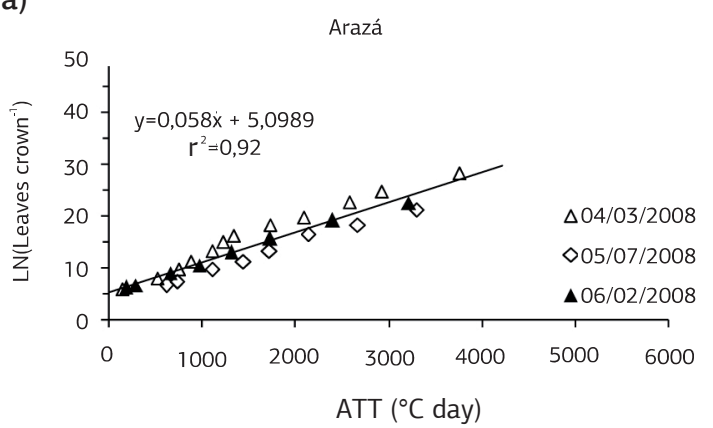

(c)

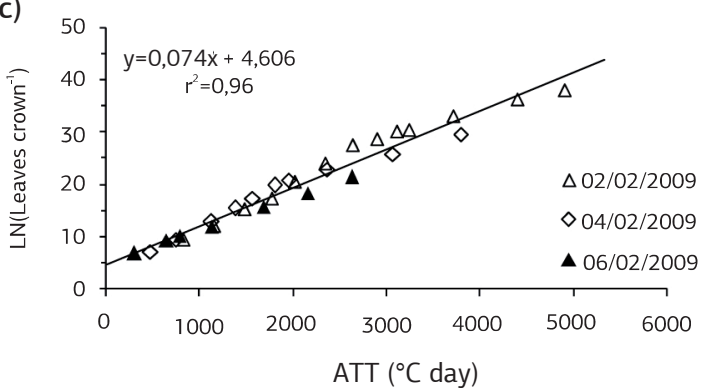

(e)

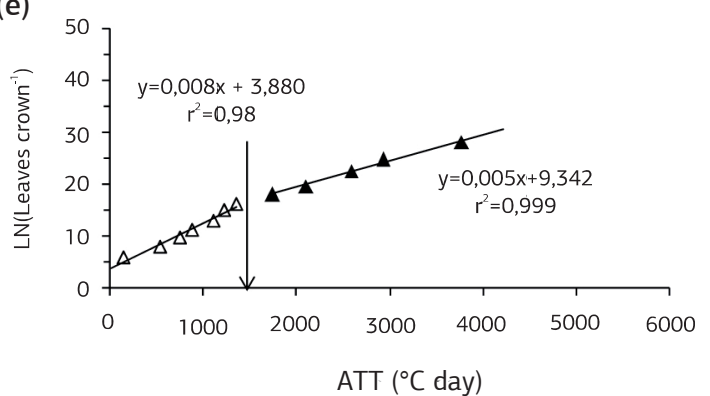

(b)

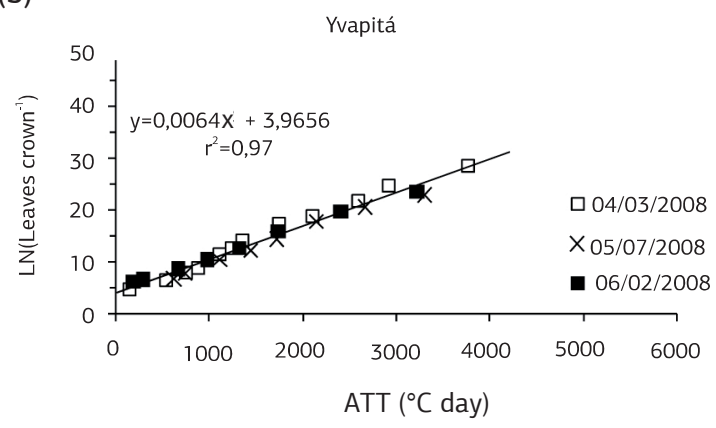

(d)

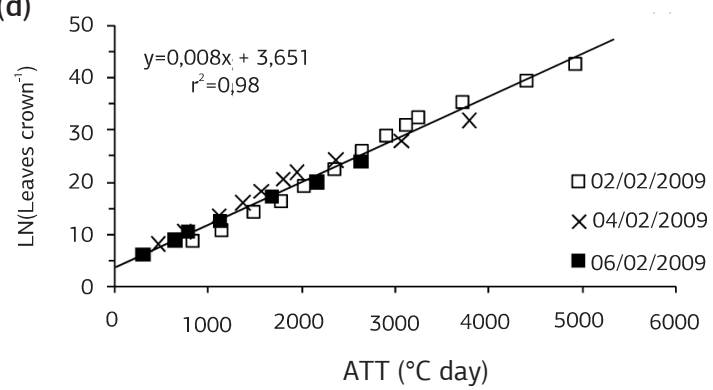

(f)

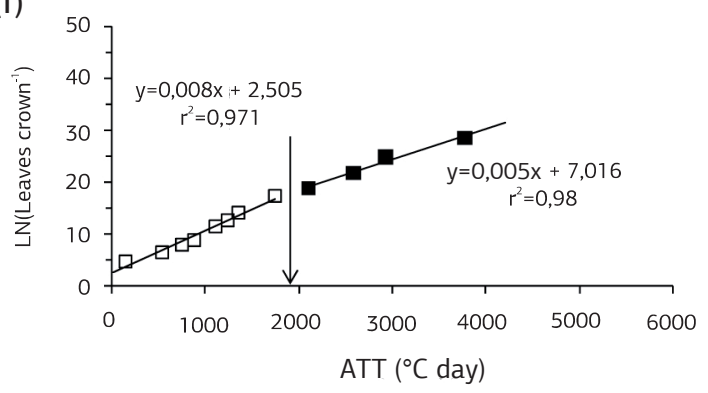

Figure 2. Relationship between accumulated leaf number on the main crown (LN) and accumulated thermal time (ATT) for two strawberry cultivars (Arazá and Yvapitá) in several planting dates (indicated inside each panel) in the 2008 (a, b) and 2009 (c, d) growing seasons, and relationship between LN and ATT in the 3/4/2008 planting date (e, f). Santa Maria (RS). Arrows in panels (e) and (f) indicate the ATT at flowering.

leaves might be affected by plant isometric relationships (McConnaughay and Coleman, 1999; Skinner and Nelson, 1995). More research is needed to test which one of these two hypotheses is predominant in strawberry plants.

Among the two cultivars, values of $\mathrm{PHYL}_{\mathrm{TOT}}$ and PHYL $_{\mathrm{FLO}}$ were greater in the cultivar Arazá, while the PHYL $_{\mathrm{VEG}}$ did not differ among cultivars (Table 1), indicating that differences in PHYL $_{\text {TOT }}$ between cultivars took place after flowering $\left(\mathrm{PHYL}_{\mathrm{FLO}}\right)$. It is important that leaf appearance rate is higher (phyllochron is lower) during the vegetative development in order to increase $\mathrm{LN}$ and LAI before flowering to enhance further fruit set and growth. After flowering, the difference in phyllochron between these two cultivars induces differences in LAI: lower PHYL $_{\mathrm{FLO}}$ in cultivar Yvapitá leads to greater LAI than in cultivar Arazá. This hypothesis was confirmed by stronger vigor in plants of the cultivar Yvapitá in all planting dates (data not shown).
Differences in phyllochron among cultivars were also reported in rice (STRECK et al., 2007), wheat (FRANCK and Bauer, 1995, Streck et al., 2005a), barley and forage grasses (Franck and Bauer, 1995). However, no differences in phyllochron were reported in some studies with winter wheat (KLepper et al., 1982). These contrasting results were probably due to the genetic distance among cultivars used in different studies. Although commercial strawberry cultivars currently used have a narrow genetic base, variations in phyllochron between the two cultivars used in this experiment suggest a high variability for this characteristic. As a consequence, strawberry cultivars respond differently to temperature, and breeding programs should include some generations of selection in environmental conditions similar to those of growers. From a practical point of view, this conclusion represents and additional and difficult task, as currently there is a small number of strawberry breeding programs around the world, mainly in America and Europe (Gimenez et al., 2003). 
Differences in phyllochron were also observed among planting dates (Table 1), with lower values in early plantings before the recommended planting time in April and May (Santos and Medeiros, 2003). Such variations may be result of a photoperiod response in strawberry. When the phyllochron before flowering was plotted against mean photoperiod during the growing period until flowering, a decreasing linear relationship was found until a photoperiod of approximately 11.8 hours, and a flat and saturating response afterwards (Figure 3). The relationship was consistently similar for both cultivars and indicates that leaf appearance rate during the plant vegetative development increases with photoperiod, a typical long-day plant response, and is in agreement with findings by Sonsteby and Heide (2006) that strawberry plants grown in short photoperiods have lower leaf appearance rates and shorter leaf petioles. These

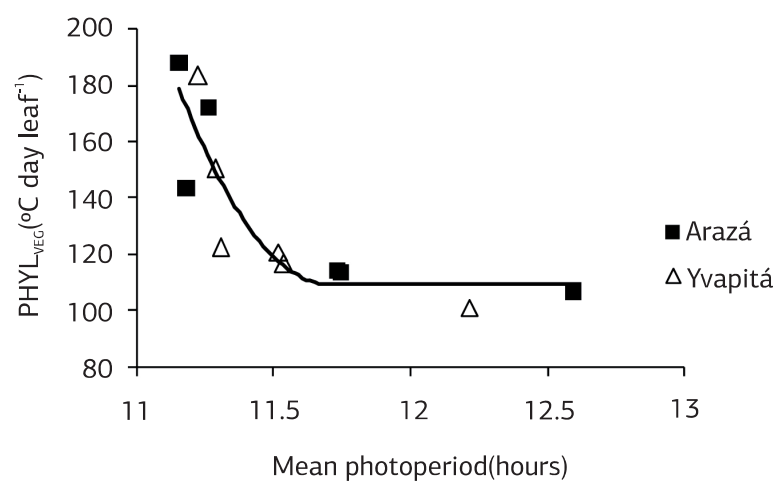

Figure 3. Relationship between phyllochron until flowering $\left(\mathrm{PHYL}_{\mathrm{VEG}}\right.$ ) and mean photoperiod from planting to flowering for two strawberry cultivars (Arazá and Yvapitá) grown in six planting dates during two growing seasons. Santa Maria (RS), 2008 and 2009.

Table 1. Means of phyllochron $\left({ }^{\circ} \mathrm{C}\right.$ day leaf $\left.{ }^{-1}\right)$ during the entire growing season $\left(\mathrm{PHYL}_{\mathrm{TOT}}\right)$, phyllochron until flowering $\left(\mathrm{PHYL}_{\mathrm{VEG}}\right)$, and phyllochron after flowering $\left(\mathrm{PHYL}_{\mathrm{FLO}}\right.$ ) of two strawberry cultivars in six planting dates, Santa Maria (RS), 2008/2009

\begin{tabular}{lccc|} 
Effect & PHYL $_{\text {TOт }}$ & PHYL $_{\text {veG }}$ & PHYL $_{\text {FLo }}$ \\
Cultivar & & & \\
\hline Arazá & $157.7 \mathrm{aB}^{*}$ & $139.4 \mathrm{aC}$ & $200,5 \mathrm{aA}$ \\
\hline Yvapitá & $140.4 \mathrm{bB}$ & $130,6 \mathrm{aB}$ & $175,6 \mathrm{bA}$ \\
\hline $\begin{array}{l}\text { Planting date } \\
\text { (month/day/year) }\end{array}$ & & & \\
\hline 2/2/2009 & $108.5 \mathrm{~dB}$ & $104.0 \mathrm{cB}$ & $183.4 \mathrm{bA}$ \\
\hline $4 / 2 / 2009$ & $142.3 \mathrm{cB}$ & $115.7 \mathrm{bcC}$ & $180.0 \mathrm{bA}$ \\
\hline $4 / 3 / 2008$ & $151.0 \mathrm{bcB}$ & $118.7 \mathrm{bcC}$ & $187.0 \mathrm{bA}$ \\
\hline $5 / 7 / 2008$ & $171.4 \mathrm{abB}$ & $161.2 \mathrm{aB}$ & $237.3 \mathrm{aA}$ \\
\hline $6 / 2 / 2008$ & $174.7 \mathrm{aA}$ & $183.5 \mathrm{aA}$ & $191.1 \mathrm{bA}$ \\
\hline $6 / 2 / 2009$ & $146.4 \mathrm{cA}$ & $127.5 \mathrm{bB}$ & $149.7 \mathrm{cA}$ \\
\hline $\mathrm{CV}(\%)^{* *}$ & 16.9 & 23.5 & 17.5 \\
\hline
\end{tabular}

* Means followed by the same lower case letters in columns within cultivars and within planting dates and upper case letters in rows are not different according to the Tukey test at $\mathrm{p}<0.05$.

** Coefficient of variation. results have implications for commercial production of strawberry seedlings, as faster emission and growth of leaves leads to higher vigor and lower production costs. The results also strengthen the previous conclusion that strawberry cultivars had to be selected in environmental conditions similar to those where fruit production will be performed.

Different from field crops, studies on basic processes, such as leaf development, in horticultural crops, including strawberry, are scarce. Furthermore, the effect of environmental variables on growth and yield of current commercial strawberry cultivars is not well understood. Our results represent an effort to fill part of this gap and thus help to determine preferential production regions, planting times and appropriate management practices for this important horticultural crop.

\section{CONCLUSION}

The base temperature for leaf appearance rate in the strawberry cultivars Arazá and Yvapitá is $0^{\circ} \mathrm{C}$. The phyllochron in strawberry varies throughout the growing season, with greater phyllochron after the onset of flowering.

Among the two strawberry cultivars, the phyllochron is similar until flowering and greater in cultivar Arazá after flowering. Among planting dates, phyllochron is greater in later planting dates (Fall and Winter) when photoperiod is shorter, a typical long-day plant response.

\section{ACKNOWLEDGMENTS}

To Coordenação de Aperfeiçoamento de Pessoal de Nivel Superior (CAPES), Conselho Nacional de Desenvolvimento Científico e Tecnológico (CNPq) and Fundação de Amparo à Pesquisa do Estado do Rio Grande do Sul (FAPERGS) for scholarships, and to INIA-Uruguay for providing mother seedlings of the strawberry cultivars.

\section{REFERENCES}

ANTUNES, O.T.; CALVETE, E.O.; ROCHA, H.C.; NIENOW A.A.; MARIANI, F.; WESP, C.L. Floração, frutificação e maturação de frutos de morangueiro cultivados em ambiente protegido. Horticultura Brasileira, v.24, p.426-463, 2006.

BRADFORD, E.; HANCOCK, J.F.; WANER, R.M. Interactions of Temperature and Photoperiod Determine Expression of Repeat Flowering in Strawberry, Journal of the American Society for Horticultural Science, v.135 p.102-107, 2010.

DURNER, E.F; BARDEN, J.A.; HIMELRICK, D.G.; POLING, E.B. Photoperiod and temperature effects on flower and runner development in day-neutral, Junebearing, and everbearing strawberries. Journal of the American Society for Horticultural Science, v.109, p.396-400, 1984. 
EMBRAPA. Sistema brasileiro de classificação de solos. Brasília: Embrapa-SPI; Embrapa-CNPS, 1999. 412p.

EMBRAPA. Sistema de produção do morango. Brasília: Embrapa, Sistemas de Produção, 5, 2005 [cited 2009 Sep 19]. Avaible from: http://www.cpact.embrapa.br/publicacoes/catalogo/tipo/sistemas/ morango/index.htm.

FRANK, A.B.; BAUER, A. Phyllochron differences in wheat, barley and forrage grasses. Crop Science, v.35, p.19-23, 1995.

GIMENEZ, G.; VICENTE, E.; MANZZIONI, A. El cultivar de frutilla INIA Arazá. Las Buxas, Instituto Nacional de Investigación Agropecuária, 2003. (Hoja de Divulgación 83)

GIMENEZ, G.; ANDRIOLO, J.L.; JÄNISCH, J.; GODOI, R. Closed soilless growing system for producing strawberry bare root transplants and runner tips. Pesquisa Agropecuária Brasileira, v.43, p.1757-1761, 2008.

HEIDE, O.M.; SONSTEBY, A. Interactions of temperature and photoperiod in the control of flowering of latitudinal and altitudinal populations of wild strawberry (Fragaria vesca). Physiologia Plantarum, v.130, p.280-289, 2007.

KLEPPER, B.; RICKMAN, R.W.; PETERSON, C.M. Quantitative characterization of vegetative development in small cereals. Agronomy Journal, v.74, p.789-792, 1982.

KIRBY, E.J.M. Factors affecting rate of leaf emergence in barley and wheat. Crop Science, v.35, p.11-19, 1995.

McCONNAUGHAY, K.D.M.; COLEMAN, J.S. Biomass allocation in plants: ontogeny or optimality? A test along three resource gradients. Ecology, v.80, p.2581-2593, 1999.

McMASTER, G.S.; WILHELM, W. Growing degree-days: one equation, two interpretations. Agricultural and Forest Meteorology, v.87, p.291-300, 1997.

ROSA, H.T.; WALTER, L.C.; STRECK, N.A.; ALBERTO, C.M. Métodos de soma térmica e datas de semeadura na determinação de filocrono de cultivares de trigo. Pesquisa Agropecuária Brasileira, v.44, p.1374-1382, 2009.

SANTOS, A.M.; MEDEIROS, A.R.M. Morango: produção. Pelotas, EMBRAPA Clima Temperado, 2003. 81p. (Frutas do Brasil 40)

SERÇE, S.; HANCOCK, J.F. The temperature and photoperiod regularion of flowering and runnering in the strawberries, Fragaria chiloensis, F. virginiana, and F. $x$ ananassa. Scientia Horticulturae, v.103, p.167-177, 2005.

SINCLAIR, T.R.; GILBERT, R.A.; PERDOMO, R.E.; SHINE JR., J.M.; POWELL, G.; MONTES, G. Sugarcane leaf area development under field conditions in Florida, USA. Field Crops Research, v.88, p.171-178, 2004.
SONSTEBY, A.; HEIDE, O.M. Dormancy relations and flowering of the strawberry cultivars Korona and Elsanta as influenced by photoperiod and temperature. Scientia Horticulturae, v.110, p. 57-67, 2006.

SKINNER, R.H.; NELSON, C.J. Elongation of the grass leaf and its relationship to the phyllochron. Crop Science, v.35, p.4-10, 1995.

STRAND, L.L. Strawberry growth and development. In: FLINT, M.L. (Ed.). Integrated pest management for strawberries. California: CAB International, 1994. (Publication 3351)

STRECK, N.A. A generalized nonlinear air temperature response function for node appearance rate in muskmelon (Cucumis melo L.). Revista Brasileira de Agrometeorologia, v.10, p.105-111, 2002.

STRECK, N.A.; WEISS, A.; XUE, Q.; BAENZIGER, P.S. Incorporating a chronology response into the prediction of leaf appearance rate in winter wheat. Annals of Botany, v.92, p.181-190, 2003a.

STRECK, N.A.; WEISS, A.; XUE, Q.; BAENZIGER, P.S. Improving predictions of developmental stages in winter wheat: a modified Wang and Engel model. Agricultural and Forest Meteorology, v.115, p.193-150, 2003b.

STRECK, N.A.; BOSCO, L.C.; MENEZES, N.L.; GARCIA, D.C.; ALBERTO, C.M.; LAGO, I. Estimativa do filocrono em cultivares de trigo de primavera. Revista Brasileira de Agrometeorologia, v.13, p.423-429, 2005a.

STRECK, N.A.; TIBOLA, T.; LAGO, I.; BURIOL, G.A.; HELDWEIN, A.B.; SCHNEIDER, F.M.; ZAGO, V. Estimativa do plastocrono em meloeiro (Cucumis melo L.) cultivado em estufa plástica em diferentes épocas do ano. Ciência Rural, v.35, p.12751280, 2005b.

STRECK, N.A.; MICHELON, S.; ROSA, H.T.; WALTER, L.C.; BOSCO, L.C.; PAULA, G.M. de; CAMERA, C.; SAMBORANHA, F.K.; MARCOLIN, E.; LOPES, S.J. Filocrono de genótipos de arroz irrigado em funçáo de época de semeadura. Ciência Rural, v.37, p.323-329, 2007.

OLIVEIRA, R.P.; SCIVITTARO, W.B. Produção de frutos de morango em funçáo de diferentes períodos de vernalização das mudas. Horticultura Brasileira, v.27, p.91-95, 2009.

TANINO, K.K; WANG, R. Modeling chilling requirement and diurnal temperature differences on flowering and yield performance in strawberry crown production. HortScience, v.43, p.2060-2065, 2008.

XUE, Q.; WEISS, A.; BAEZINGER, P.S. Predicting leaf appearance in field-grown winter wheat: evaluating linear and non-linear models. Ecological Modeling, v.175, p.261-270, 2004. 